\title{
LA POLÍTICA DEL YO: CIENCIA PSICOLÓGICA Y SUBJETIVIDAD BURGUESA EN LA ESPAÑA DEL SIGLO XIX"
}

\author{
Enric J. Novella** \\ Centro de Ciencias Humanas y Sociales (CSIC)
}

\section{RESUMEN}

En este artículo se ofrece un análisis del proceso de institucionalización del conocimiento psicológico en España por obra de las reformas educativas implementadas durante el segundo tercio del siglo XIX, que prescribieron su inclusión en el programa curricular de la nueva educación secundaria. Tras un examen detenido de la orientación doctrinal, los supuestos ideológicos y la filiación sociopolítica de los contenidos transmitidos a los alumnos durante la mayor parte de la centuria, se interpreta su espiritualismo militante como un intento muy significativo por parte de las élites liberales de articular una pedagogía de la subjetividad destinada a contrarrestar las tendencias de reducción, naturalización y fragmentación del psiquismo alentadas por el desarrollo de la ciencia moderna.

PALABRAS CLAVE: Psicología. Subjetividad. Educación secundaria. Espiritualismo. España. Siglo XIX.

\section{THE POLITICS OF THE SELF: PSYCHOLOGICAL SCIENCE AND BOUR- GEOIS SUBJECTIVITY IN 19TH CENTURY SPAIN}

\begin{abstract}
This paper offers an analysis of the process of institutionalization of psychological knowledge in Spain following the educative reforms implemented during the second third of the $19^{\text {th }}$ century, which prescribed its inclusion in the curricular program of the new secondary education. After a detailed examination of the theoretical orientation, the ideological assumptions and the sociopolitical connections of the contents transmitted to the students throughout the century, its militant spiritualism is interpreted as a highly significant attempt on the part of the liberal elites to articulate
\end{abstract}

* Trabajo realizado en el marco de los proyectos HAR2008-04899-C02-01 (Ministerio de Ciencia e Innovación) y 52007/HUM-0512 (Comunidad de Madrid).

** Investigador contratado doctor (Programa JAE-Doc), Centro de Ciencias Humanas y Sociales (CSIC), C/ Albasanz 26-28, 28037 Madrid (España), Tel.: +34916022934, Correo electrónico: enric.novella@cchs.csic.es. 
a pedagogy of subjectivity intended to counteract the trends toward reduction, naturalization and fragmentation of psychic life inherent to the development of modern science.

KEY WORDS: Psychology. Subjectivity. Secondary education. Spiritualism. Spain-19th century.

El yo es siempre uno, idéntico y activo; y todo él es sensible, inteligente y libre.

José Soriano y Castro

Alumno del Instituto San Isidro de Madrid (1849)

\section{INTRODUCCIÓN}

«Individualismo se llama, en lo social y político, la nota específica del siglo XIX. La corriente individualista es un nuevo incremento de la subjetividad» ${ }^{1}$. Estas palabras de Antonio Machado, escritas cuando la distancia histórica empezaba a permitir una mirada retrospectiva con respecto a la herencia del ochocientos, constituyen un excelente punto de partida para advertir las coordenadas culturales en las que cabe situar el notable impulso de los saberes psicológicos durante el siglo XIX. Como una disciplina distintivamente burguesa cuya difusión e institucionalización acompañan de forma característica el despliegue de la Modernidad, la psicología ha sido objeto de un constante interés por parte de los historiadores de las ciencias humanas, advirtiéndose en los últimos años un notable esfuerzo por situar sus aportaciones en el marco más amplio de una historia social, cultural e incluso política de la subjetividad. Desde este punto de vista, la evolución y la extraordinaria proyección del conocimiento psicológico en los últimos doscientos años resultan inseparables de la emergencia de un homo psychologicus, esto es, de una cultura de la subjetividad definida por la reflexividad, la promoción de la interioridad y la paulatina adscripción de las claves de la identidad personal al ámbito del psiquismo2. Consecuentemente, los trabajos inspirados por este

1 Machado, A. (1989), Prosas completas, Madrid, Espasa-Calpe y Fundación Antonio Machado (original de 1931), p. 1782.

2 Para una visión preliminar de la articulación histórica de esta cultura de la subjetividad y de los aspectos fundamentales que la conforman pueden consultarse, entre otros, los trabajos de Renaut, A. (1993), La era del individuo: Contribución a una historia de la subjetividad, Barcelona, Destino; TAYlor, C. (1996), Fuentes del yo: La construcción de la identidad moderna, Barcelona, Paidós; CRUZ, M. (comp.) (1996), Tiempo de subjetividad, Barcelona, Paidós; Fetz, R.L., Hagenbüchle, R. y Schulz, P. (eds.) (1998), Geschichte und Vorgeschichte der modernen Subjektivität, Berlín, De Gruyter; BÜRGER. P. y BÜRGER, C. (2001), 
planteamiento han tratado de analizar no sólo el modo en que este contexto cultural ha condicionado la formación de los saberes psicológicos, sino también su propia implantación en tanto que marcos de autocomprensión que mueven a los individuos a verse y a actuar de una determinada manera con respecto a sí mismos ${ }^{3}$.

En el caso de la España del siglo XIX, el estudio histórico de la evolución y la difusión del conocimiento psicológico desde esta óptica cultural permanece como un territorio básicamente inexplorado. Así, a pesar de la gran labor realizada en el ámbito de la historia de las ideas, apenas existen trabajos que hayan abordado la inserción de los saberes psicológicos en el contexto de las nuevas pautas culturales e ideológicas que acompañan el paulatino desmantelamiento político, económico y social del Antiguo Régimen a lo largo de las décadas centrales del siglo ${ }^{4}$. Este periodo, que en lo esencial coincide con el

La desaparición del sujeto: Una historia de la subjetividad de Montaigne a Blanchot, Madrid, Akal. Una interesante revisión del «progreso de la conciencia psicológica» como correlato de la Modernidad se ofrece en BÉJAR, H. (1993), La cultura del yo: Pasiones colectivas y afectos propios en la teoría social, Madrid, Alianza.

3 Entre los trabajos que asumen de un modo u otro esta perspectiva de análisis, cabe citar Jüttemann, G. (ed.) (1986), Die Geschichtlichkeit des Seelischen: Der historische Zugang zum Gegenstand der Psychologie, Weinheim, Beltz Verlag; DANZIGER, K. (1990), Constructing the Subject: Historical origins of psychological research, Cambridge, Cambridge University Press; Rose, N. (1990), Governing the Soul: The shaping of the private self, Londres, Routledge; Staeuble, I. (1991), Psychological man and human subjectivity in historical perspective, History of the Human Sciences, 4, pp. 417-432; CusHman, P. (1995), Constructing the Self, Constructing America: A cultural history of psychotherapy, Reading MA, Addison-Wesley; Pfister, J. y SCHNOG, N. (eds.) (1997), Inventing the Psychological: Towards a cultural history of emotional life in America, New Haven, Yale University Press; Rose, N. (1999), Inventing Our Selves: Psychology, power and personhood, Cambridge, Cambridge University Press; GoldsteIn, J. (2005), The Post-Revolutionary Self: Politics and psyche in France 1750-1850, Cambridge MA, Harvard University Press; THOMSON, M. (2006), Psychological Subjects: Identity, health and culture in 20th Century England, Oxford, Oxford University Press. El estudio de Jan Goldstein, al que me referiré más adelante, constituye un ejemplo particularmente logrado de indagación histórica sobre los estrechos vínculos entre la ideología, la cultura y la evolución del conocimiento psicológico en el marco específico de la Francia pre y posrevolucionaria. Véase NoveLLA, E.J. (2009), De la historia de la psiquiatría a la historia de la subjetividad, Asclepio, LXI (2), pp- 261-280.

4 Cabe exceptuar, en este sentido, algunos de los estudios compilados en BlANCO, F. (ed.) (1997), Historia de la psicología española: Desde una perspectiva socio-institucional, Madrid, Biblioteca Nueva. Desde el punto de vista de la historia de las ideas, la obra más completa sigue siendo CARPINTERO, H. (2004), Historia de la psicología en España, Madrid, Pirámide. 
reinado de Isabel II (1833-1868), asistió, como se sabe, no sólo a la substitución del absolutismo por una monarquía constitucional inspirada en fórmulas de soberanía compartida, sino también a la emergencia de una incipiente economía capitalista y de un modelo clasista de organización social basado en la hegemonía normativa de los principios de libertad, igualdad y -sobre todopropiedad $^{5}$. A nivel ideológico y cultural, se trata de una época marcada por el liberalismo y el romanticismo, que, si bien adquieren en España unos caracteres singulares derivados de las particularidades del país, también lo sitúan en una mayor consonancia con las coordenadas político-culturales de la Europa del momento ${ }^{6}$. Ambos movimientos suponen, como bien advertía Antonio Machado, la definitiva entrada en escena del individualismo contemporáneo, que, por un lado, entroniza la condición básica del individuo como sujeto de derechos y átomo social y, por el otro, promueve en él una reflexividad que le conmina a poner de manifiesto su originalidad y su singularidad ${ }^{7}$. Consecuentemente, la experiencia individual, la exploración de estados psicológicos o la búsqueda de la «verdad interior» se convierten en una motivación constante de la creación artística y literaria española del periodo, hasta el punto de que algunos de sus más lúcidos exponentes advierten en la centralidad de lo subjetivo el rasgo esencial del espíritu de los tiempos y lo vinculan de forma explícita con el programa de emancipación política articulado en el ideario liberal ${ }^{8}$.

5 Así, por ejemplo, la introducción de un aparato estatal y administrativo de corte burocrático o racional, la abolición de las viejas estructuras gremiales y la consagración de la libertad de industria y comercio, la universalización de la condición de ciudadano o el surgimiento de una burguesía urbana crecientemente numerosa e influyente son fenómenos muy característicos de la transición a la sociedad moderna que aparecen en España justamente durante este periodo. Cf. ARTOLA, M. (1974), La burguesía revolucionaria (1808-1874), Madrid, Alianza; Jover ZAMORA, J.M.' (1992), La civilización española a mediados del siglo XIX, Madrid, Espasa-Calpe; Fuentes, J.F. (2007), El fin del Antiguo Régimen (1808-1868): Política y sociedad, Madrid, Síntesis; o FontanA, J. (2007), La época del liberalismo, Barcelona, Crítica/Marcial Pons.

6 Buenas visiones de conjunto de la evolución del pensamiento y la cultura española durante este periodo se ofrecen en ABELLÁN, J.L. (1984), Historia crítica del pensamiento español, Vol. 4: Liberalismo y romanticismo (1808-1874), Madrid, Espasa-Calpe; JURETSCHKE, H. (coord.) (1989), La época del romanticismo (1808-1874), Historia de España dirigida por Menéndez Pidal, Vol. XXXV, Madrid, Espasa-Calpe; y Serrano García, R. (2001), El fin del Antiguo Régimen (1808-1868): Cultura y vida cotidiana, Madrid, Síntesis.

7 Cf. Fernández Sebastián, J. (2002), Individualismo. En Fernández SEbastián, J. y FuENTES, J.M. (eds.), Diccionario político y social del siglo XIX español, Madrid, Alianza, pp. 371-379.

8 Testimonios en este sentido pueden encontrarse, por ejemplo, en las obras de dos autores tan representativos de la época como Larra o Alcalá Galiano. Cf. KIRKPATRICK, S. (1991), 
En estas circunstancias, resulta muy significativo que la aparición de la psicología como disciplina académica se produjera en España precisamente con las reformas educativas liberales de la década de 1840, y que esta aparición, además, se diera por medio de su inclusión en el currículo formativo de la nueva educación secundaria. Este hecho, que ha sido certeramente analizado en el marco de los cambios introducidos en la «filosofía oficial» por el nuevo Estado liberal ${ }^{9}$, constituye también un fenómeno muy indicativo desde el punto de vista de la cultura de la subjetividad, y ello por varias razones. En primer lugar, porque ratifica que el psiquismo y sus atributos han asumido ya una presencia cultural y una posición en el orden del saber que les confieren una cierta entidad o substantividad como objetos de conocimiento. En segundo lugar, porque sugiere que el poder liberal atiende unas determinadas demandas ideológicas o persigue unos intereses específicos al fomentar la difusión y la orientación doctrinal de dicho conocimiento. $\mathrm{Y}$, por último, porque cabe suponer que la implantación pedagógica de una disciplina de estas características va a tener una notable resonancia cultural al incidir justamente en la visión que sus destinatarios tienen de sí mismos.

El presente artículo aspira a ser una primera aproximación al estudio de la evolución, las implicaciones sociopolíticas y la proyección cultural de este caudal de conocimiento psicológico que acompañó al advenimiento y consolidación de la España liberal. Con este objeto, describiré brevemente el proceso histórico-legislativo que, paralelamente a la institucionalización de la nueva educación secundaria, condujo a la aparición de la psicología como disciplina académica por obra de las reformas educativas implementadas a lo largo del segundo tercio del siglo XIX. Posteriormente trataré de mostrar los supuestos ideológicos y la impronta distintivamente burguesa del espiritualismo militante transmitido en las aulas de los institutos españoles de la época, ofreciendo un examen comparativo de sus versiones ecléctica, neoescolástica y krausista. Centrado en el ámbito de lo que podríamos definir como una pedagogía o política de la subjetividad, el análisis mostrará cómo la introduc-

Las románticas: Escritoras y subjetividad en España 1835-1850, Madrid, Cátedra/Instituto de la Mujer, pp. 47-56.

9 Véase, en este sentido, la espléndida monografía de Heredia, A. (1982), Política docente y filosofia oficial en la España del siglo XIX: La era isabelina (1833-1868), Salamanca, Instituto de Ciencias de la Educación, donde se expone con gran detalle y precisión el paso desde la Escolástica tradicional a la Ideología espiritualista y al espiritualismo ecléctico consumado en España durante este periodo. Para una visión crítica de este proceso resulta interesante todavía consultar las ácidas diatribas de MenÉndez Pelayo, M. (1992), Historia de los heterodoxos españoles, Madrid, CSIC (original de 1882), Vol. 2, pp. 1257-1281. 
ción de la psicología y la difusión del espiritualismo burgués en la España del siglo XIX constituyen un fenómeno muy significativo no sólo desde el punto de vista de la historia de las ideas, sino también desde una perspectiva social y cultural más amplia.

\section{LA PSICOLOGÍA EN LAS REFORMAS EDUCATIVAS LIBERALES}

El 17 de septiembre de 1845, Pedro José Pidal, ministro de la Gobernación del primer gabinete del general Narváez y distinguida figura del liberalismo doctrinario español, obtenía de Isabel II la firma del Real Decreto por el que se aprobaba un nuevo Plan General de Estudios. El Plan, en cuya elaboración desempeñó un destacado papel el entonces Director General de Instrucción Pública Antonio Gil de Zárate ${ }^{10}$, supuso un hito decisivo en la consolidación del orden educativo impulsado por el nuevo Estado liberal, teniendo, a pesar de las múltiples reformas y modificaciones a las que fue sometido en años posteriores, un carácter seminal con respecto a las líneas maestras de la política educativa española durante buena parte del siglo XIX ${ }^{11}$. En lo que aquí interesa, el Plan Pidal supuso, por un lado, la consagración definitiva de la enseñanza media o secundaria como un nivel educativo con una organización, unos objetivos y unos contenidos singulares e independientes de la formación universitaria $^{12}$, y, por el otro, la emergencia en el currículo formativo de una materia con la denominación específica de «psicología». Así, en el tercero de

10 De hecho, Gil de Zárate, que fue también un notable dramaturgo y estudioso de la literatura, publicó diez años después una importante colección de materiales que todavía hoy resultan de gran interés para conocer el proceso de gestación, los principios ideológicos y los contenidos concretos del Plan (GIL DE ZÁRATE, A. (1855), De la instrucción pública en Espa$\tilde{n} a$, Madrid, Imprenta del Colegio de Sordomudos).

11 La aprobación del Plan constituyó, de hecho, un acontecimiento muy señalado en la vida política y social del país, haciéndose eco de ella la práctica totalidad de la prensa y siendo incluso extensamente comentada por grandes personalidades del momento como Jaime Balmes (Cf. Balmes, J. (1845), El nuevo plan de estudios, El Pensamiento de la Nación, I, pp. 657-662, 673-679, 689-694, 705-710 y 721-726). Un balance detallado de la significación histórica del Plan Pidal se ofrece en Heredia (1982), pp. 197-236, y en Delgado CRiAdo, B. (1994), Historia de la educación en España y América, Vol. 3: La educación en la España contemporánea (1789-1975), Madrid, Ediciones SM, pp. 58-67.

12 Cf. PeSet M. y PeSet, J.L. (1974), La universidad española (siglos XVIII y XIX): Despotismo ilustrado y revolución liberal, Madrid, Taurus, pp. 581-613; o VIÑAO FraGO, A. (1982), Política y educación en los orígenes de la España contemporánea. Examen especial de sus relaciones en la enseñanza secundaria, Madrid, Siglo XXI, pp. 354-396. 
los cinco cursos de que había de constar la enseñanza secundaria elemental (a cuyo término se obtenía el grado de Bachiller en Filosofía) se incluyó una asignatura denominada «Principios de psicología, ideología y lógica» que aspiraba a compendiar los contenidos propiamente filosóficos del bachillerato y los escindía definitivamente de la enseñanza moral y religiosa, relegada a partir de ese momento a unos «Principios de moral y religión» impartidos en el segundo curso ${ }^{13}$.

Más allá de repetidas menciones a la «educación moral» como elemento vertebrador y objetivo primordial de los estudios secundarios, ni el preámbulo expositivo del Plan ni los materiales compilados por Gil de Zárate contienen una justificación precisa de los fines de la nueva asignatura, si bien es posible inferir el lugar de ésta en el marco de la orientación renovadora con que el Plan, colmando una vieja aspiración del reformismo educativo liberal, acometió la reorganización de los estudios filosóficos. Frente a la Escolástica, que, como soporte racional de la ortodoxia católica, había mantenido durante siglos una posición de privilegio en las instituciones educativas españolas, ya los liberales doceañistas y del Trienio habían propuesto la introducción de la lógica y la gramática general de inspiración empírico-sensista ${ }^{14}$ como las materias filosóficas a impartir en los nuevos institutos o «universidades de provincias» ${ }^{15}$. Abortados estos intentos por el plan absolutista de 1824 (que reinstauró la Metafísica escolástica), el Plan presentado en agosto de 1836 por el Duque de Rivas establecía los «Elementos de ideología» como la asignatura que debía compendiar la formación filosófica del bachillerato ${ }^{16}$, introdu-

13 Véase el artículo tercero del Plan y el texto completo de éste en DE PUELLES, M. (Ed.) (1985), Historia de la educación en España, $2^{\mathrm{a}}$ ed., Vol. 2: De las Cortes de Cádiz a la Revolución de 1868, Madrid, Ministerio de Educación y Ciencia, pp. 193-239. No en vano, uno de los objetivos fundamentales de la reforma fue justamente la «completa secularización» de la enseñanza, que el mismo Gil de Zárate consideraba entonces como «una de sus primeras y más urgentes necesidades» (GIL DE ZÁrATE (1855), Vol. 1, p. 116).

14 El sensualismo o sensismo epistemológico tuvo una amplia difusión en España durante el primer tercio del siglo XIX, impregnando ampliamente el espíritu de renovación pedagógica de los primeros liberales. Uno de los focos más activos en este sentido fue la llamada Escuela de Salamanca, cuyos miembros redactaron un importante informe sobre los proyectos de reforma de la instrucción pública propuestos a las Cortes de Cádiz. Cf. ABELlán (1984), pp. 181-203.

15 Así lo recogen tanto el Proyecto de Decreto presentado en 1814 a las Cortes de Cádiz por una comisión encabezada por Manuel J. Quintana como el Reglamento General de Instrucción Pública aprobado en 1821. El texto completo de ambos documentos puede consultarse en De Puelles (1985), pp. 377-396 y 49-67.

16 Véase el texto del Real Decreto de 4 de agosto de 1836 aprobando el Plan General de Instrucción Pública en De Puelles (1985), pp. 123-148. Debido a los acontecimientos de La 
ciendo así una denominación que durante años serviría de facto para designar a la filosofía no escolástica.

En esas coordenadas, la psicología hizo su aparición efectiva en los contenidos de la educación secundaria española hacia finales de la década de 1830, asumiendo un protagonismo muy evidente en los libros de texto más influyentes de la época. Así, el Manual clásico de filosofía de Étienne ServantBeauvais, publicado en 1838 en traducción libre de José López de Uribe (Catedrático de Lógica y Gramática General en los Estudios de San Isidro de Madrid y, posteriormente, de Metafísica en la Universidad Central) y que fue el texto escolar que gozó de mayor implantación de entre los aprobados por la Dirección General de Estudios hasta 1843, incluía ya una amplia sección de psicología en la que ésta era definida como la «ciencia del alma o la conciencia», constituyendo así «la parte fundamental de la filosofía, [a la que] compete describir y explicar las propiedades del alma humana, así como las causas y principios de la inteligencia y la moralidad» ${ }^{17}$. Por su parte, el canónigo gaditano Juan José Arbolí, autor de otro de los manuales destacados del momento, llegaba a afirmar incluso que:

(...) la filosofía se comprende toda en la psicología [pues] para que las máximas reguladoras del entendimiento y de la voluntad del hombre sean acertadas y legítimas, es indispensable que se deriven del conocimiento profundo de su naturaleza intelectual y moral, cuyo estudio corresponde a la psicología ${ }^{18}$.

En realidad, pues, las disposiciones del Plan Pidal no hicieron más que reflejar y sancionar oficialmente la prominencia del discurso psicológico en la cultura filosófica posrevolucionaria, reproduciendo un proceso que, de hecho, los liberales franceses habían completado en 1832. Ese año, y tras la revisión de los programas de educación secundaria promovida por François Guizot, la enseñanza de la filosofía en los liceos empezó a incluir una extensa sección

Granja, el Plan del Duque de Rivas fue derogado un mes después de su aprobación, si bien fue prontamente sustituido por un «Arreglo provisional de estudios» que, reintroduciendo la denominación de «Lógica y principios de gramática general», mantuvo la misma línea de renovación de los estudios filosóficos. Cf. HEREDIA (1982), pp. 51-131.

17 Citado por HEREDIA (1982), p. 181.

18 Arbolí, J.J. (1844), Compendio de lecciones de filosofía, Cádiz, Imprenta de la Revista Médica, pp. 18-19. Véase el extenso comentario dedicado a los manuales de ServantBeauvais y Arbolí en HEREDIA (1982), pp. 175-193 y 409-413, que los considera, respectivamente, como los textos escolares más representativos de la Ideología espiritualista y el espiritualismo ecléctico en la España isabelina. 
inicial de psicología cuyos contenidos fueron directamente propuestos por Victor Cousin ${ }^{19}$. Cousin, como es sabido, fue durante décadas el máximo exponente del eclecticismo filosófico francés, alentando desde sus diversos cargos públicos la institucionalización de una psicología espiritualista que, inspirada a partes iguales por el idealismo alemán y la escuela escocesa del siglo XVIII, se convirtió en seña de identidad del pensamiento doctrinario ${ }^{20}$. De este modo, la irrupción de la psicología en las aulas españolas y su posterior prescripción por el Plan Pidal han de verse en el contexto de la rápida penetración y difusión de la Ideología espiritualista y el espiritualismo ecléctico entre las élites del régimen isabelino, a las que, como en Francia, proporcionó un sistema filosófico que encajaba particularmente bien con los intereses del moderantismo político burgués. Comentando este giro en el ámbito del «pensamiento oficial», Antonio Heredia ha señalado con acierto que:

Si en los tiempos de la Guerra de la Independencia y de Riego los liberales pudieron defender posiciones radicales en política y adscribirse sin ambages a la ideología pura y racional; ahora, después de una dura y rica experiencia, se hacen doctrinarios y matizan su sensualismo. En el fondo, lo que estaba triunfando [...] era una nueva actitud social, una virtus civilis de alcance reformista: el espíritu ecléctico, llamado a convertirse en insignia de todo un reinado ${ }^{21}$.

Los postulados psicológicos del espiritualismo ecléctico tuvieron, de hecho, una difusión masiva en España durante la década de 1840, consignándose en obras como las Lecciones de filosofía ecléctica (1843) impartidas en el Ateneo de Madrid por Tomás García de Luna y el ya citado Compendio de lecciones de filosofía (1844) de Arbolí22. Asimismo, habría que añadir las prontas traducciones y la rápida implantación de varios manuales escolares redactados por discípulos de Cousin, como las Lecciones de filosofía (1843) de J.P. Damiron, el Curso completo de filosofía para la enseñanza de amplia-

19 Para un análisis detallado de este proceso, véase GOLDSTEIN (2005), pp. 182-194.

20 Cf. Chase, R.R. (1989), The influence of psychology on Guizot and orleanist policies, French History, 3, pp. 177-193; DíEz Del CoRRAL, L. (1998), El liberalismo doctrinario. En Obras completas, Madrid, Centro de Estudios Políticos y Constitucionales, Vol. 1, pp. 145155; y GOLDSTEIN (2005), pp. 139-181.

21 Heredia (1982), p. 16. Véase también Peset y Peset (1974), pp. 635-642; Abellán (1984), pp. 318-345; y DíEz DEL CORRAL (1998), pp. 373-421. Este proceso ha sido analizado también desde el punto de vista de una sociología de los intelectuales por VILLACORTA, F. (1980), Burguesía y cultura: Los intelectuales españoles en la sociedad liberal (1808-1931), Madrid, Siglo XXI, pp. 26-52.

22 Cf. CARPintero (2004), pp. 64-67. 
ción (1846) de M.J. Tissot, el Curso de filosofia (1847) de E. Géruzez, el Curso de filosofía sobre el fundamento de las ideas absolutas de lo verdadero, lo bello y lo bueno (1847) del propio Cousin o el Manual de filosofía para el uso de los colegios (1848) de A. Jacques, J. Simon y E. Saisset. Cabe recordar, por lo demás, que Gil de Zárate fue repetidamente acusado de haber transcrito directa y discrecionalmente los programas de Cousin ${ }^{23}$, apreciación que, al menos en lo que concierne a los contenidos de la nueva «psicología» del bachillerato, es, como pronto veremos, esencialmente correcta.

En cualquier caso, la asignatura se mantuvo, si bien con algunas modificaciones menores, en los planes educativos posteriores, formando parte integral de los contenidos filosóficos de la educación secundaria hasta bien entrado el siglo $\mathrm{XX}^{24}$. Así, por ejemplo, los planes de los ministros Pastor Díaz (1847) y Seijas (1850) simplificaron su denominación a la de «Psicología y lógica», ubicándola en el quinto curso de la enseñanza media ${ }^{25}$. Por su parte, la célebre Ley de Instrucción Pública de 1857 situaba los mismos «Elementos de psicología y lógica» en el sexto y último curso ${ }^{26}$, si bien el Programa General de Estudios de Segunda Enseñanza hecho público un año después les añadía por vez primera una sección de ética ${ }^{27}$. A partir de 1861, de hecho, la asignatura pasó a denominarse «Psicología, lógica y filosofía moral» 28 , denominación que, tras ser transitoriamente revisada en los planes del ministro Orovio

23 Véase, por ejemplo, De La ReVILla, J. (1854), Breve reseña de la instrucción pública en España, con relación especial a los estudios de filosofía, Madrid, Imprenta de Eusebio Aguado; MenÉndez Pelayo (1992), Vol. 2, p. 1193.

24 Véanse Utande Igualada, M. (comp.) (1964), Planes de estudio de enseñanza media (1787-1963), Madrid, Ministerio de Educación Nacional; FEY, E. (1975), Estudio documental de la filosofía en el Bachillerato español (1807-1957), Madrid, CSIC; CASTRO, J., DE CASTRO, R. y CASLA, M. (1997), Las Cátedras de Filosofía de los Institutos de Segunda Enseñanza: el control ideológico de la educación. En Blanco, F. (1997), Historia de la psicología española: Desde una perspectiva socio-institucional, Madrid, Biblioteca Nueva, pp. 109-144, pp. 116-117.

25 Véase el cuadro de asignaturas de ambos planes en PESET y PESET (1974), pp. 591-592.

26 Véase el artículo decimoquinto de la Ley y el texto completo de ésta en DE PUELLES (1985), pp. 245-300.

27 Véase el artículo segundo del Programa en los Programas generales de estudios aprobados por S.M. en 26 de agosto y 11 y 20 de setiembre de 1858, Madrid, Imprenta Nacional (1858), p. 12.

28 Cf. el artículo segundo del Real Decreto de 21 de agosto de 1861 modificando el Plan de Estudios de Segunda Enseñanza (Colección Legislativa de España (CLE), Vol. 86, pp. 206-210). 
(1866-1867) ${ }^{29}$ y durante el Sexenio revolucionario $(1868-1874)^{30}$, fue asumida por el primer plan de estudios de la Restauración $(1880)^{31} \mathrm{y}$, por tanto, se mantuvo vigente hasta los años finales del siglo XIX.

\section{ESPIRITUALISMO Y SUBJETIVIDAD BURGUESA}

El afán regulador y centralizador de los sucesivos gabinetes liberales en materia educativa facilita enormemente al historiador la tarea de reconstruir la orientación doctrinal, los supuestos ideológicos e incluso la filiación sociopolítica de los contenidos de la «psicología» impartida a partir de 1845 en las aulas españolas de secundaria. Así, disponemos tanto de los programas de la asignatura elaborados en los años subsiguientes por la Dirección General de Instrucción Pública ${ }^{32}$ como de una amplia serie de manuales y libros de texto que, de acuerdo con dichos programas, fueron siendo publicados por algunos de sus docentes en los institutos del país. La política de «libre elección restringida» seguida por el régimen isabelino con respecto a los libros de texto hizo que sólo algunos de ellos contaran con aprobación oficial, observándose entre estos un claro predominio doctrinal del eclecticismo que, a partir de la década de 1860, se complementaría con la inclusión de algunos textos de inspiración neoescolástica ${ }^{33}$.

29 Orovio, en concreto, planteó inicialmente escindir la asignatura en tres cursos independientes de psicología, lógica y ética (Cf. CLE, Vol. 96, pp. 681-688), pero el Reglamento de Segunda Enseñanza aprobado el 15 de julio de 1867 bajo sus auspicios mantuvo las cosas como estaban (Cf. CLE. Vol. 98, pp. 108-155).

30 El Plan de Estudios aprobado el 3 de junio de 1873 a instancias del ministro Eduardo Chao pretendió sustituir la asignatura por una «Antropología o ciencia del hombre considerado en su espíritu, en su cuerpo y en la relación entre ambos» (Cf. CLE, Vol. 110, pp. 14431454), pero el Plan fue anulado y no llegó a entrar en vigor debido a la caída del gobierno republicano de Nicolás Salmerón en septiembre del mismo año (Cf. CLE, Vol. 111, p. 354).

31 Cf. CLE, Vol. 125, pp. 205-227.

32 Véase su compilación en Programas para la asignatura de filosofía publicados por la Dirección General de Instrucción Pública, Madrid, Imprenta Nacional (1846); y Programas para las asignaturas de segunda enseñanza mandadas observar por S.M. en todos los institutos, seminarios y colegios del reino por Real Orden de 20 de setiembre de 1850, Madrid, Imprenta Nacional (1850).

33 Véase Heredia (1982), pp. 395-407, donde se incluye la lista completa de los textos escolares de filosofía (incluyendo los de psicología, lógica y ética) aprobados entre 1845 y 1868. Dentro de su pretensión de uniformidad, el Plan Pidal había establecido que los manuales lectivos de las diversas asignaturas debían elegirse entre los incluidos en una lista a publi- 
En líneas generales, los contenidos prescritos en los primeros programas oficiales tenían, como ya se ha sugerido, un acusado perfil espiritualista, enfatizándose en ellos la dualidad esencial de cuerpo y alma, la naturaleza unitaria, activa e inmaterial del «yo» como elemento organizador de la interioridad psíquica y su división en las esferas tradicionales de la psicología de las facultades (sensibilidad, inteligencia y voluntad). El programa de 1850, en este sentido, instaba al profesor de la asignatura a:

Definir la psicología manifestando detenidamente la existencia del alma, su distinción sustancial del cuerpo y de la materia, sus atributos de unidad, identidad y actividad y las facultades primarias e irreductibles del YO humano (sic), a saber: la sensibilidad, la inteligencia y la voluntad ${ }^{34}$.

Por su parte, el «estudio analítico de las facultades del alma», que ocupaba la mayor parte del temario, era concebido en los términos de una «psicología experimental» especialmente interesada en avalar la legitimidad epistémica de los datos ofrecidos por la «percepción interna (conciencia)», la existencia de la «libertad moral» y la falsedad intrínseca y aberrante del materialismo. Este esquema, que se completaba con un breve apartado final dedicado a la «síntesis de las facultades», fue seguido de forma reglamentaria por la práctica totalidad de los manuales escolares hasta las décadas finales del siglo XIX, si bien introduciendo algunos matices importantes en función de la filiación teórica e ideológica de sus autores.

En cualquier caso, si hay un libro de texto que representa la ortodoxia espiritualista a partir de la cual pueden apreciarse estos matices, éste es, sin duda, el curso de Elementos de psicología debido al polígrafo e higienista catalán Pedro Felipe Monlau (1808-1871), que, entre sus numerosos cargos y destinos, fue desde 1848 a 1857 Catedrático de Psicología y Lógica en el Instituto de San Isidro de Madrid ${ }^{35}$. El curso de Monlau, publicado junto con una

car trianualmente por el Consejo de Instrucción Pública. Esta práctica, formalmente abolida por el Ministerio de Manuel Ruiz Zorrilla tras la Revolución de 1868, fue retomada durante la Restauración hasta la introducción del sistema de cuestionarios en 1901. Cf. VILLALAín BENITO, J.L. (1997), Manuales escolares en España, Vol. I: Legislación (1812-1939), Madrid, UNED.

34 Programas para las asignaturas de segunda enseñanza mandadas observar por S.M. en todos los institutos, seminarios y colegios del reino por Real Orden de 20 de setiembre de 1850, Madrid, Imprenta Nacional (1850), p. 53.

35 Cf. Monlau y Sala, J. (1864), Relación de los estudios, grados, méritos, servicios y obras cientificas y literarias del Ilmo. Sr. Dr. D. Pedro Felipe Monlau, Madrid, Imprenta y Estereotipia de M. Rivadeneyra, pp. 18-19. Sobre la figura y la obra de Monlau pueden con- 
amplia sección de lógica redactada por el filósofo cordobés José María Rey Heredia (1818-1861), fue, de hecho, el libro de texto de psicología más recomendado por el Consejo de Instrucción Pública en sus listas trianuales ${ }^{36}$, gozando inicialmente de una buena reputación entre los sectores más conservadores y afines al régimen y resultando después, en comparación con los manuales de la escuela ultramontana, igualmente aceptable para los docentes de tendencia más progresista. Consecuentemente, fue reeditado hasta trece veces entre 1849 y 1894, lo que demuestra que su uso escolar llegó a estar tan arraigado que, a pesar de la paulatina aparición de textos más actualizados, pervivió hasta el periodo de entresiglos ${ }^{37}$.

Desde el punto de vista doctrinal, y aunque algunos autores han querido ver en él un «positivismo primerizo», la presencia de «interesantes aportaciones psicofisiológicas» o un intento de «conciliar la psicología con los supuestos de la ciencia experimental» ${ }^{38}$, lo cierto es que una lectura atenta de sus sucesivas ediciones desmiente estas apreciaciones y confirma su total adscripción al espiritualismo oficial de inspiración ecléctica. En este sentido, y aunque ocasionalmente llegue a subrayar la «gran utilidad de los estudios fisiológicos para ilustración del psicólogo» ${ }^{39}$, Monlau desarrolla los contenidos del temario (la existencia y la inmortalidad del alma, su substantivación

sultarse las monografías de GRANJEL, M. (1983), Pedro Felipe Monlau y la higiene española del siglo XIX, Salamanca, Ediciones Universidad de Salamanca; y CAMPOS, R. (2003), Monlau, Rubio, Giné. Curar y gobernar: Medicina y liberalismo en la España del siglo XIX, Madrid, Nívola.

36 En concreto, el manual fue recomendado por todas las listas oficiales de libros de texto para las asignaturas de educación secundaria hechas públicas entre el 22 de septiembre de 1849 y el 1 de agosto de 1868. Cf. HeREDIA (1982), p. 406. La importancia de los «Elementos» de Monlau desde el punto de vista gubernamental queda avalada por el hecho de que su exclusión momentánea de la lista publicada el 18 de septiembre de 1853 forzó, sólo una semana después, la promulgación de una Real Orden con el objetivo expreso de restituirlos. El texto de esta orden puede consultarse en CLE, Vol. 60, p. 154.

37 Como, de hecho, han comprobado CASTRO, De CASTRO y CASLa (1997), pp. 119-140.

38 Respectivamente CASTRO, De CASTRO y CASLA (1997), p. 121; CARreras y ARTAU, T. (1952), Médicos-filósofos españoles del siglo XIX, Barcelona, CSIC, pp. 52-55; y SANTACAtalina, I. (1980), El «Curso de psicología» (1849) de Pedro Felipe Monlau. En GARMA, S. (ed.), El científico español ante su historia: la ciencia en España entre 1750-1850, Madrid, Diputación Provincial de Madrid, pp. 261-262. Véanse también las apreciaciones similares de DOMÉNECH, E. y RAICH, R.M. (1985), Antecedents de l'ensenyament de la psicologia a Catalunya en el segle XIX, Gimbernat, 4, pp. 95-107; y CARPINTERO (2004), pp. 68-69.

39 Monlau, P.F. (1849), Elementos de psicología. En Monlau, P.F. y Rey Heredia, J.M., Curso de psicología y lógica, Madrid, Imprenta La Publicidad, p. 31. 
psíquica en el yo, los atributos de unidad, identidad y actividad de este, la división tripartita de las facultades, etc.) de un modo tan explícito y unívoco que no deja lugar a dudas ${ }^{40}$. Por todos estos motivos, su curso constituye una fuente de gran valor en la historia educativa y cultural de la España de la segunda mitad del siglo XIX, permitiendo acometer un análisis más detallado de los contenidos efectivamente transmitidos durante décadas a los alumnos españoles por medio de la psicología del bachillerato y, de este modo, de la pedagogía de la subjetividad implementada con ella por el régimen liberal.

De acuerdo con los planteamientos cousinianos, Monlau insiste, en primer lugar, en la gran importancia propedéutica de la psicología («punto de partida, antecedente necesario, y única base de todas las teorías filosóficas»), subrayando en todo momento su alto valor cultural y la gran relevancia social de sus aportaciones:

Lo que encumbra a la psicología sobre las demás ciencias, es la importancia de su objeto; y bajo este punto de vista, no sólo exige ser considerada como la primera de las ciencias, sino que reclama ser cultivada con singular esmero por todos los amigos de la verdad y de la humanidad. Con efecto: ¿hay algo más digno de nuestras especulaciones, hay algo más útil, hay algo más grandioso en sus resultados, que la ciencia que revela el hombre a sí mismo, que le inicia en los sublimes misterios de su naturaleza, que le descubre el secreto de su fuerza, que le eleva por la contemplación de su ser hasta el principio del cual emanan sus nobles facultades, y le explica el destino a que éstas le llaman? [...] Se comprenderá que es la ciencia realmente civilizadora [a la que] corresponde explorar y gobernar el mundo moral, dirigiendo a los individuos y a las sociedades por los caminos que haya trazado el conocimiento de la naturaleza y del destino de la especie humana ${ }^{41}$.

Desde el punto de vista individual, la psicología constituye, eso sí, una disciplina selecta y exigente (y, por tanto, incompatible con una «vida liviana y de pura exterioridad»), pues requiere «una naturaleza rica y profunda [y] una gran fuerza de reflexión para recogerse dentro de sí y fijar en el laboratorio mental los fenómenos de la vida anímica $\rangle^{42}$. Monlau, que, significativamente, situó como lema de su obra la célebre inscripción del templo de Delfos «conócete a ti mismo» (el gnothi sautou griego o nosce te ipsum latino),

40 «La pura observación interna, y no el escalpelo, es con efecto la que tiene el derecho de contar y describir las facultades anímicas. No recusamos el auxilio de las ciencias fisiológicas $[\ldots]$ pero sí decimos que sin ellas puede subsistir y ha subsistido la ciencia del alma» (MONLAU (1849), pp. 55-56).

41 Monlau (1849), p. 18 (cursivas mías, E.N.).

42 Monlau (1849), p. 19. 
otorga así a la introspección un papel esencial en el proceso de individuación, pues sólo ella puede permitir al sujeto su autoaprehensión como «fuerza cogitante, sensible y moral»y, por tanto, el ejercicio consciente de sus fines («sentir la belleza, conocer la verdad y obrar libremente el bien»):

La conciencia es el foco de todas las demás capacidades que tenemos: es el elemento esencial y la condición subjetiva invariable del ejercicio de todas las funciones. Por la conciencia reflexiva el hombre es hombre, y se distingue de las cosas. Por la energía mayor o menor de la reflexión un hombre se hace superior a otro. Sin la conciencia, en fin, no habría verdadera vida moral o psicológica ${ }^{43}$.

Ciertamente, el ejercicio de la reflexión debe practicarse con mesura, pues los excesos del «estudio» o de la «vida contemplativa» pueden conducir a una pérdida de la «energía corporal»e incluso de la salud de forma análoga a la imaginación, la cual, si no se halla gobernada por la razón, «crea quimeras, ilusiones y monstruos, hace castillos en el aire, hace soñar al hombre despierto $\mathrm{y}$ no pocas veces ocasiona la locura $\rangle^{44}$. Pero la indagación honesta de uno mismo es indispensable para aprehender el «yo», esto es, para desarrollar una adecuada «conciencia de sí», reconocerse como «sustancia espiritual»y, de este modo, instituirse como «criatura moral». No en vano:

(...) todos empezamos siendo materialistas primero que espiritualistas, por la misma razón que todos empezamos a balbucear antes que a hablar con soltura [...]. Pero la educación y la reflexión hacen caer pronto todas esas ilusiones; la conciencia habla bien claro al que la consulta de buena fe. [...] Examínese el lector a sí mismo, recójase por un momento en el silencio de la meditación, y pronto confesará que la existencia del alma, o de una sustancia distinta del cuerpo, es una verdad palpable, un hecho de conciencia inmediata, clara, distinta, fuera de toda duda, y que no necesita demostración. [...] El que después de haberse observado interiormente, afecta creer que en el hombre no hay más que cuerpo, es un desgraciado que cierra los oídos a la voz de la conciencia, esperando neciamente encontrar la impunidad de sus vicios y devaneos ${ }^{45}$.

En consonancia, el alma es definida por Monlau como una «fuerza libre e ilustrada» cuya naturaleza es, ante todo, la «actividad» o aquel «esfuerzo voluntario» al que aludía Maine de Biran:

43 Monlau (1866), Elementos de psicología. En Monlau y Rey Heredia, Curso de psicología y lógica, $7^{\mathrm{a}}$ ed., Madrid, Imprenta y Estereotipia de M. Rivadeneyra, p. 46.

44 Monlau (1849), p. 182.

45 Monlau (1849), pp. 23-25 (cursivas en el original). 
La vida del alma es una vida que se conoce a sí misma, una fuerza autonómica o que se dirige por sí, y que tiene conciencia de su energía y de sus facultades; es una causa libre, es una vita sui conscia, sui potens, sui motrix. [...] Las fuerzas físicas son autómatas; la fuerza psíquica es autócrata ${ }^{46}$.

En estas coordenadas, el estudio de las facultades ofrecido en la extensa sección de «psicología experimental» va a definir la voluntad (y no la inteligencia o la sensibilidad) como el elemento verdaderamente distintivo e incluso constitutivo del psiquismo humano: la voluntad es, como afirmaba Descartes, «lo más propiamente nuestro que hay en nosotros, o mas bien la voluntad es nosotros mismos, y ella sola constituye, por decirlo así, la persona humana. [...] La voluntad es plenamente nuestra. La voluntad es el YO (sic)» $\rangle^{47}$.

Si recopilamos brevemente los postulados básicos de todo este entramado doctrinal, vemos que, antes que nada, la progresión de la conciencia (de la espontaneidad a la reflexión) y la evolución doctrinal de la propia psicología (del materialismo al espiritualismo) se conciertan mutuamente al servicio del libre albedrío y en contra del determinismo. Nos encontramos, pues, ante una psicología en la que la existencia de la libertad y la responsabilidad moral «se demuestra directamente por la conciencia»: «La conciencia de sí misma es a la vez la condición necesaria y suficiente para que una fuerza sea libre» ${ }^{48}$. Y esto es así hasta el punto de que, para Monlau, «todas las libertades naturales, civiles y políticas» se derivan, justamente, de la «libertad psicológica» que implica la autodisposición del yo ${ }^{49}$.

Teniendo en cuenta el carácter prescriptivo de los contenidos representados canónicamente por el manual de Monlau, así como la identidad de sus destinatarios, no resulta difícil advertir cómo el campo del psiquismo fue definido por las élites liberales como un escenario conformado a la medida de una serie de principios ideológicos muy concretos. En primer lugar, la «conciencia de sí» substantivada en el yo aparece, como hemos visto, como el fundamento último de la individualidad y como una posesión íntima e inalienable del sujeto que, de forma análoga a los bienes materiales, emerge de forma evidente y a priori del orden natural de las cosas. De hecho, la legitimación de la propiedad privada a partir de la constitución «natural» del psi-

46 Monlau (1849), pp. $41-42$ (cursivas en el original). En la séptima edición de 1866, Monlau define el yo justamente como «esa causa sentida dentro de nosotros mismos y conocida inmediatamente en sí» (MONLAU (1866), p. 16 (cursivas en el original)).

47 MONLAU (1849), pp. 51-52 (cursivas y mayúsculas en el original).

48 Monlau (1849), p. 53.

49 Monlau (1849), p. 85. 
quismo fue una línea de argumentación muy extendida en la filosofía de la primera mitad del siglo XIX, y, muy particularmente, entre los Ideólogos y eclécticos franceses ${ }^{50}$. Y en España, por ejemplo, el presidente del Liceo Valenciano justificaba en una conferencia publicada en 1841 el origen de la idea de propiedad en unos términos muy similares:

Desde que el individuo conoce claramente su yo, su persona moral y su capacidad de gozar y sufrir y de hacer, ve también necesariamente que este yo es propietario exclusivo del cuerpo que él vivifica, de los órganos que mueve, de todas sus facultades, de todas sus fuerzas y de todos los efectos que producen sus acciones y pasiones. [...] La idea de propiedad y de propiedad exclusiva, nace pues necesariamente del hecho solo de ser susceptible de pasión y de acción, y nace solamente porque está dotado de una propiedad inevitable e inalienable, que es la de su individualidad ${ }^{51}$.

Unas décadas después, la irrupción del movimiento obrero y la difusión del socialismo reforzarían la vigencia de este argumento entre los sectores más conservadores, hasta el punto de que en 1880 Luis Laplana y Ciria, Catedrático del Instituto de Zaragoza, no vacilaba en asegurar a sus alumnos que «el socialismo anula por completo al individuo entero, quitándole hasta la conciencia de sí mismo» ${ }^{52}$.

Asimismo, la desigual distribución del talento para la reflexión y la «sublime complejidad» de la ciencia psicológica hacen que, a pesar de que, como señala Monlau, sus virtudes «civilizadoras» deberían convertirla en el «punto de partida de todo sistema de educación», el conocimiento de esa «síntesis tan admirable y misteriosa» que es el yo deba quedar reservado a una pequeña élite. En un contexto sociopolítico marcado por el sufragio censitario y la escasa integración de las masas populares, su estudio se incluyó, no por casualidad, en los planes formativos de la nueva educación secundaria, nivel que el propio Gil de Zárate describió con gran pompa como aquél que:

50 Cf. Goldstein (2005), pp. 162-165. En este sentido, es bien conocida la opinión de Marx sobre Destutt de Tracy, a quien acusaba de haber querido «demostrar que propriété, individualité y personnalité son cosas idénticas y que en el moi va implícito también el mien» (MArX, K. y Engels, F. (1969), Die deutsche Ideologie. En Werke, Berlín, Dietz Verlag (original de 1845-1846), Vol. 3, p. 210, cursivas en el original).

51 JuANES, J. (1841), Origen y comprensión de la idea de propiedad, Liceo Valenciano, 1(2S), pp. 58-69, pp. 63-64.

52 LAPlana y CiRia, L. (1880), Manual de psicología, lógica y ética, Zaragoza, S.E., p. 76. 
(...) se dirige a las clases altas y medias, esto es, a las más activas y emprendedoras; a las que se hallan apoderadas de los principales puestos del Estado y de las profesiones que más capacidad requieren; a las que legislan y gobiernan; a las que escriben, inventan, dirigen, y dan impulso a la sociedad, conduciéndola por las diferentes vías de la civilización; en suma, a las que son el alma de las naciones, conmueven los pueblos y causan su felicidad o su desgracia ${ }^{53}$.

En este sentido, resulta altamente indicativo que la psicología no sólo se excluyera de la educación primaria, popular o profesional, sino también de los planes formativos de las Escuelas Normales encargadas de la preparación de los maestros, que no incluyeron disciplinas pedagógicas o psicológicas hasta bien entrado el siglo $\mathrm{XX}^{54}$.

Cabe señalar, además, que, frente a la visión fragmentaria y pasiva del psiquismo alentada por la epistemología sensualista, el énfasis espiritualista en el carácter unitario y activo del yo y la asimilación de éste a la voluntad constituye un planteamiento muy afín a la comprensión que de sí misma tenía la burguesía liberal de mediados del siglo XIX, tan propensa a concebir su creciente influencia en términos de talento, esfuerzo y moderación ${ }^{55}$. Por último, conviene destacar también el interés de la nueva psicología en avalar la legitimidad gnoseológica y la importancia cultural del autoconocimiento, si bien alertando en todo momento de los riesgos del solipsismo introspectivo o los excesos de la imaginación. La introspección, ese noble «movimiento de reflexión», debe arrojar, en todos los casos, un mismo y predecible resultado: la autodeterminación de la voluntad, que, por un lado, posibilita al hombre el ejercicio consciente de su libertad y la consecución de sus fines, pero, por el otro, lo sitúa en un universo moral del que no puede ni debe escapar. En síntesis, pues, puede decirse que los contenidos psicológicos prescritos por las élites liberales proponían una reflexividad programática y plenamente secular, en tanto en cuanto ni sus métodos ni sus objetivos requieren ya la mediación

53 Gil De ZÁrate (1855), Vol. 2, p.1 (cursivas mías, E.N.). Para una revisión del debate sobre el carácter, contenidos y destinatarios de la nueva educación secundaria en la España del siglo XIX, véase ViÑAO FrAGO (1982), pp. 432-467, cuyas estimaciones sitúan para el año 1857-1858 el número de estudiantes de bachillerato entre el 2 y el 4,5 por 100 del total de la población en edad de cursarlo. Por lo demás, véase JOVER ZAMORA (1992), pp. 192-207, para una discusión de la estricta oposición entre la élite de «ciudadanos» con derechos y los «súbditos» pertenecientes a las clases populares durante el régimen isabelino.

54 Cf. Delgado CRiado (1994), pp. 168-177 y 396-401.

55 Véase, en este sentido, HoBSBAWM, E.J. (1997), La era de la revolución (1789-1848), Barcelona, Crítica, pp. 187-204. 
o se dirigen hacia el encuentro con la divinidad ${ }^{56}$; pero se trataba, en cualquier caso, de una reflexividad poco ambiciosa cuyos atributos esenciales remitían, en última instancia, a las tradicionales virtudes burguesas de la laboriosidad, la contención y la responsabilidad moral.

\section{BORDEANDO LA ORTODOXIA: NEOESCOLÁSTICA Y KRAUSISMO}

Una vez revisados los principios básicos y la impronta distintivamente burguesa de la psicología espiritualista mayoritariamente difundida a partir de 1845 en las aulas españolas, conviene completar la exposición con el tratamiento del discurso psicológico por parte de las dos corrientes de pensamiento que, a partir de la década de 1860, se disputaron la hegemonía ideológica en el campo de la educación filosófica. Estas dos corrientes son, como es sabido, la neoescolástica católica y el idealismo krausista, que, una vez iniciado el declive del eclecticismo francés, consiguieron infiltrar con sus adeptos las cátedras de numerosos institutos de educación secundaria y tomaron a su cargo la enseñanza de las materias filosóficas llevada a cabo en ellos ${ }^{57}$. Lógicamente, cabe suponer que estos docentes trataron de transmitir a los alumnos los fundamentos de sus respectivas posiciones teóricas, las cuales, tomadas desde un punto de vista estrictamente filosófico, no podían resultar más contrapuestas. Así, frente al énfasis de los pensadores neocatólicos en la primacía de la fe sobre la razón, su impugnación del giro subjetivista consumado por la filosofía moderna y su pretensión de restaurar la metafísica escolástica, el «racionalismo armónico» de los krausistas constituía un idealismo progresista que alentaba un espíritu de renovación ética, científica y política de hondas raíces ilustradas ${ }^{58}$. Sin embargo, constreñidos - a excepción del

56 Véase GoldSTEIN (2005), pp. 233-268, para una excelente contraposición de las vías religiosa y secular de acceso a la interioridad en el contexto de la Francia decimonónica. De todos modos, la importancia de la experiencia religiosa en el proceso de constitución del sujeto psicológico moderno, intuida ya ferozmente por Nietzsche, ha sido subrayada por una larga lista de autores que pasa por Charles Taylor o el mismo Ortega. Ambos, por ejemplo, atribuyen a San Agustín nada menos que la formulación paradigmática de la «reflexividad radical» que caracteriza la conciencia psicológica moderna. Cf. ORTEGA Y GASSET, J. (1985), ¿Qué es filosofia?, Madrid, Alianza (Original de 1937), pp. 135-150; y TAYLOR (1996), pp. 127-158.

57 Véase nuevamente CASTRO, De CASTRO Y CASLA (1997), pp. 119-140.

58 Para una exposición sumaria de los principios filosóficos de la neoescolástica y el krausismo español pueden consultarse, respectivamente, FORMENT GIRALT, E. (1998), Historia de la filosofía tomista en la España contemporánea, Madrid, Ediciones Encuentro; y Ló- 
breve interludio del Sexenio - en los márgenes impuestos por los diferentes programas y disposiciones oficiales, los contenidos psicológicos impartidos por los docentes de ambas orientaciones y reflejados en sus manuales y libros de texto más representativos no se desviaron tanto de la ortodoxia reinante como podría suponerse, si bien aportaron algunos matices importantes que merecen ser considerados aquí.

Por lo que respecta a la neoescolástica y al tradicionalismo católico, conviene señalar de antemano que siempre albergó profundas reservas frente al «psicologismo» de la nueva filosofía oficial, al que llegó a calificar como «un error que recibimos y saludamos sin conocerlo, llevados de la propensión que hemos tenido y aún tenemos a imitar y traducir todo lo malo de Francia» ${ }^{59}$. Así, Gabino Tejado, conocido publicista católico, traductor de un importante manual de filosofía escolástica ${ }^{60}$ y discípulo de Donoso Cortés, glosaba la obra de éste en la prensa católica de 1853 en unos términos en los que se refleja con claridad la oposición de los sectores tradicionalistas a toda filosofía centrada en la epistemología o la psicología:

Precisamente ha vivido [Donoso] para hacer la guerra á esta miserable psicología de nuestros días, cuyo principio es: «que se necesita sanar la inteligencia del hombre, que está enferma, para encaminar al supremo bien su voluntad, que no está tímida y descaminada, sino porque está enferma su inteligencia». El principio de que parte Donoso es diametralmente opuesto: «es necesario sanar la voluntad del hombre, que está enferma, para comunicar luz y reposo a su inteligencia, que no está conturbada y estremecida, sino porque está enferma su voluntad» ${ }^{61}$.

En cualquier caso, estos sectores apreciaron el espiritualismo de la nueva psicología, valorando su papel preventivo frente a los «dos grandes escollos que son la Escila y la Caribdis de la ciencia moderna, el materialismo y el

PEZ-MoRiLlas, J. (1980), El krausismo español: Perfil de una aventura intelectual, $2^{\mathrm{a}}$ ed., Madrid, FCE. Sobre el krausismo, véase también TERRÓn, E. (1969), Sociedad e ideología en los orígenes de la España contemporánea, Barcelona, Península; ABELLÁn (1984), pp. 394-511. Para una síntesis del pensamiento psicológico de ambas escuelas, CARPINTERO (2004), pp. 79-97.

59 Ortí Y LARA, J.M. (1867), Las cinco llagas de la enseñanza pública (citado por HEREDIA (1982), p. 391).

60 Tejado tradujo y editó en 1866 los Elementos de filosofía especulativa según las doctrinas de los escolásticos, y singularmente de Santo Tomás de Aquino del presbítero italiano José Prisco, que gozó de una cierta difusión pues fue recomendado por el gobierno para los estudios superiores de filosofía el 22 de septiembre de 1867. Cf. HEREDIA (1982), p. 407.

61 Tejado, G. (1853), Don Juan Donoso Cortés, Marqués de Valdegamas, El Áncora, 23 de junio, 1355. 
racionalismo, grosero y miserable el uno, delicado y sublime el otro, pero ambos errores a cual más trascendentales» ${ }^{62}$. En su edición del 6 de junio de 1849, el periódico católico La Esperanza reconocía en este sentido que «ha hecho, eso sí, la filosofía contemporánea un servicio que nunca podremos desconocer [...]: reconocer la espiritualidad del alma, elemento de por sí muy poderoso contra la corrupción que ha soltado todos los diques». En la misma línea, dos meses después el periódico se hacía eco de la publicación del Curso de Monlau y Rey con una reseña muy elogiosa, en la que se aseguraba que el libro:

(...) llena un gran vacío, y hasta nos hace presagiar una verdadera restauración de los buenos estudios filosóficos. [...] En la psicología hemos advertido mucha exactitud y mucha profundidad de análisis, complaciéndonos en gran manera la verdad y hasta la elocuencia con que son combatidos los errores de Condillac, y pulverizadas las perniciosas teorías de las escuelas sensualistas. [...] Es regular que existiendo una obra elemental tan recomendable, disponga el gobierno que sea sustituida como libro de texto a esos indigestos prontuarios y mal forjados compendios que inundan el mercado científico, llenando de absurdos la cabeza de la juventud, y pervirtiendo quizás su corazón ${ }^{63}$.

De hecho, a pesar de que el espiritualismo ecléctico llegó a ser retrospectivamente definido por los autores neocatólicos como «recreativo, incoherente y vago» o incluso abiertamente acusado de panteísmo ${ }^{64}$, los docentes cercanos a la neoescolástica respetaron en sus cursos, al menos inicialmente, una transmisión relativamente completa y fiel de los contenidos psicológicos prescritos en los programas oficiales ${ }^{65}$. Todavía en el curso 1861-62, por ejemplo, una figura clave del movimiento neocatólico como el filósofo Juan Manuel Ortí y Lara, Catedrático de Metafísica en la Universidad Central a partir de 1876, explicaba

62 La cita procede de otro libro de texto incluido en las listas oficiales de la época (GUTIÉRrez DíAZ, A. (1860), Curso completo de filosofía elemental, Santander, Imprenta de los Hijos de Martínez, Vol. 1, p. VI).

63 La Esperanza, 2 de agosto de 1849, 1487.

64 Véanse, respectivamente, MENÉNDEZ Pelayo (1992), Vol. 2, p. 1259; ORTí Y LARA, J. M. (1852), Curso elemental de filosofía, Granada, Imprenta de José M. ${ }^{a}$ Zamora, pp. 145-147; o GonzÁlez, Z. (1864), Estudios sobre la filosofía de Santo Tomás, Manila, Establecimiento Tipográfico del Colegio de Santo Tomás, Vol.1, pp. 374-402.

65 Como prueba un examen somero de sus manuales escolares, entre los que cabe mencionar los Elementos de psicología y lógica (1854) del presbítero Juan Díaz de Baeza (Director del Instituto de San Isidro en la década de 1850 y docente ocasional de la asignatura), las Lecciones de psicología (1863) del también presbítero Salvador Mestres (Catedrático en el Instituto de Barcelona) o los Cursos de Agustín Gutiérrez y Ortí y Lara citados, respectivamente, en las notas 62 y 64 . 
«Psicología y lógica» a sus alumnos del Instituto del Noviciado de Madrid con el Curso de Monlau y Rey como libro de cabecera ${ }^{66}$.

Ciertamente, conforme la reacción neocatólica fue ganando en influencia a partir de la segunda mitad de la década de 1860, algunos de los catedráticos alineados con sus planteamientos fueron imprimiendo un sello más distintivo a sus manuales escolares. En la edición de 1868 de su Psicología, el propio Ortí situaba ya su obra en el marco de la «restauración de las sanas doctrinas filosóficas que se va rápidamente haciendo no ya sólo en otras naciones sino también en nuestra patria», de manera que, sin alejarse por completo de los contenidos oficiales, alteró la división habitual de la materia en psicología «racional» $\mathrm{y}$ «experimental» e introdujo una extensa sección de metafísica escolástica en la que insistía en la jerarquía de las facultades volitivas e intelectivas sobre las sensitivas ${ }^{67}$. Otros autores, por su parte, se limitaron a desarrollar o privilegiar aquellos aspectos del temario que les parecían más importantes desde el punto de vista de los axiomas doctrinales del catolicismo, como la finalidad religiosa del autoconocimiento o la propia inmortalidad del alma. Así, frente a la introspección «secular» promovida por la psicología ecléctica, el sacerdote Francisco Teodoro Mosquera explicaba a sus alumnos de Valladolid que el examen interior de los estados del alma sólo podía remitir, de acuerdo con los principios de la espiritualidad religiosa tradicional, a la idea de la divinidad:

El hombre, al reconocerse como un ser ó substancia, ve necesariamente que su existencia contingente es producto de otro ser; y la imposibilidad de afirmar que un

66 Cf. Memoria acerca del estado de la enseñanza en la Universidad Central y en los establecimientos de su distrito, en el Curso de 1860 a 1861 y Anuario de 1861 a 1862, Madrid, Imprenta de José M. ${ }^{a}$ Ducazcal (1862), pp. 316-329.

67 Ortí Y LARA (1868), Psicología, 4 a ed., Madrid, Imprenta de Tejado. Siguiendo al neotomista italiano Sanseverino, Ortí distribuyó los contenidos en una «dinamilogía», una «idealogía» (sic) y una «antropología», a las que correspondía, respectivamente, el estudio de las facultades (o «potencias») del alma, las ideas y la naturaleza del alma. Véase una reseña crítica de la obra en Revista de España (1868), 3, pp. 339-341. Es interesante mencionar, además, que esta edición incluía dos apéndices destinados a combatir los supuestos de dos doctrinas psicológicas que Ortí consideraba particularmente perniciosas, a saber, el magnetismo animal y la frenología. La denuncia de la frenología como un sistema que «echa por tierra o por lo menos pone en peligro la espiritualidad e inmortalidad del alma humana [y] se opone a la moral y la religión» fue asumida también por otra figura destacada de la neoescolástica de la época como Fray Zeferino González, que publicó en 1873 un manual escolar de filosofía que tuvo una amplia implantación en los centros educativos religiosos. Cf. GoNZÁLEZ, Z. (1873), Filosofia elemental, Madrid, Imprenta de Policarpo López, pp. 315-325. 
ser contingente no dependa [de] un ser necesario, criador y productor de todos los seres contingentes. Esto creemos [...] de todos los seres corpóreos conocidos por la percepción externa, y de todos los inmateriales conocidos por el sentido íntimo y la inducción 68 .

Manuel Polo y Peyrolón, que fue Catedrático de Psicología, Lógica y Filosofía Moral en el Instituto de Valencia antes de convertirse en un destacado diputado y senador del Partido Carlista, consideraba que la inmortalidad del alma no era sino el «término natural y consolador de la ciencia psicológica», por lo que su manual, muy reeditado, se completaba con un capítulo final destinado a «demostrarla» ${ }^{69}$. En todo caso, cabe retener que, bien por su prescripción gubernativa o por su mayor compatibilidad con los dogmas de la fe, los docentes neocatólicos participaron activamente en la difusión del espiritualismo psicológico oficial, al que consideraban, en suma, como un mal menor frente a los «errores más trascendentales, mas dañosos y más hábiles» encarnados por el sensualismo, la frenología o el positivismo ${ }^{70}$.

Salvando las distancias, conclusiones similares pueden aplicarse al movimiento krausista, cuyos docentes y manuales escolares de psicología se movieron también, al menos hasta la inflexión positivista iniciada a partir de la segunda mitad de la década de 1870, en unas coordenadas netamente espiritualistas. De hecho, a pesar de la conocida animadversión que Julián Sanz del Río, el fundador de la escuela, sentía hacia Cousin y la filosofía francesa ${ }^{71}$, los contenidos psicológicos que recomendó para la Segunda Enseñanza no divergían en exceso de los consignados en los manuales eclécticos, como prueba el programa de «Psicología, lógica y ética» que publicó originalmente entre 1861 y 1862 en varias separatas de la Revista Ibérica de Ciencias. Este programa constituye un documento ejemplar del ethos pedagógico krausista y reviste un gran interés por los comentarios didácticos con los que Sanz del Río orienta el desempeño del profesor en tanto «artista de enseñanza» encargado de transmitir a sus alumnos los «hábitos de reflexión psicológica, de

68 Mosquera, F.T. (1869), Enchiridion, ó sea Manual de psicología, lógica y ética, Valladolid, Imprenta de Gaviria y Zapatero, p. 71.

69 Cf. Polo y Peyrolón, M. (1879), Elementos de psicología, Valencia, Imprenta de Manuel Alufre, pp. 243-254. Concretamente, el manual de Polo tuvo cinco ediciones, apareciendo la última en 1902.

70 La expresión procede de HERnÁNDEZ FAJARnÉS, A. (1883), La psicología celular, Zaragoza, Imprenta de La Derecha, p. VI.

71 Sobre la «galofobia» intelectual de Sanz del Río, incluyendo su célebre y decepcionante encuentro de juventud con Cousin, véase LóPEZ-MoriLlas (1980), pp. 23-24 y 110-114. 
razonamiento lógico, de recta, firme y elevada voluntad en toda su conducta científica y social, privada y pública» ${ }^{72}$; sin embargo, sus contenidos doctrinales, como se ha dicho, reproducen en lo esencial los puntos fundamentales de la ortodoxia espiritualista. Significativamente, Sanz del Río se abstiene, eso sí, de incluir la inmortalidad del alma entre los axiomas psicológicos, y, en su intención de «dar a la doctrina relaciones prácticas y de aplicación», subraya en varias ocasiones la importancia de instruir a los estudiantes en «reglas, consejos y máximas concretas de higiene del alma» ${ }^{73}$.

Entre los manuales krausistas hay que destacar también las Lecciones sumarias de psicología de Francisco Giner de los Ríos, compiladas por sus discípulos Eduardo Soler y Alfredo Calderón a partir de las clases de Giner en la Escuela de Institutrices de Madrid. En la primera edición, aparecida en 1874, el fundador de la Institución Libre de Enseñanza explota las virtualidades psicológicas del idealismo krausista de un modo más decidido que el propio Sanz del Río, si bien no se aparta en ningún momento del esquema tradicional y del consabido énfasis en la naturaleza espiritual del yo, el estudio convencional de las facultades y una visión de la psicología más cercana a la propedéutica filosófica que al saber especializado ${ }^{74}$. En este punto, sus comentarios sobre la «evidente utilidad de nuestra ciencia» resultan muy instructivos, pues reflejan en clave krausista la misma ecuación entre introspección, individuación y sentido ético de la existencia que veíamos articulada en la psicología de inspiración ecléctica:

Por [la psicología] conoce el hombre la naturaleza de su espíritu, distingue sus verdaderos fines y descubre las fuerzas y medios de que dispone para alcanzarlos; discierne las necesidades reales de su Alma de las artificiales y perversas, nacidas de una educación dañosa, y halla siempre el bien en amoroso acuerdo con sus inclinaciones y tendencias, pudiendo así cumplirlo de buen grado [...] con esa virtud

72 Sanz Del Río, J. (1862), Programas de Segunda Enseñanza. Psicología, lógica y ética, Madrid, Imprenta de Manuel Galiano, p. 2 (cursivas en el original).

73 SANZ Del Río (1862), pp. 6 y 25. Curiosamente, Sanz del Río dedicó gran atención filosófica a la cuestión de la inmortalidad del alma, que él, con argumentos un tanto idiosincrásicos, consideraba fuera de toda duda. Cf. SALES y FerRÉ, M. (1877), Filosofia de la muerte: Estudio hecho sobre manuscritos de Julián Sanz del Río, Sevilla, Imprenta de José G. Fernández.

74 Cabe recordar, en este sentido, las palabras de Heinrich Ahrens, destacado discípulo de Krause y autor de un conocido Curso de psicología que fue traducido al castellano sólo un año antes de la aparición de las Lecciones de Giner: «El espíritu es la fuente de toda ciencia filosófica, y la ciencia que se ocupa de él, de su naturaleza, de sus facultades y de sus manifestaciones es la base y punto de partida de toda investigación ulterior» (AHRENS, H. (1873), Curso de psicología dado en París, Madrid, Aribau y C., Vol. 1, pp. 5-6). 
ascética de que necesitamos en la vida cuando para cumplir el deber tenemos que sofocar viciados impulsos. Con el estudio de la Psicología se arraiga más en el hombre el sentimiento de su dignidad racional, y, en suma, se cumple el antiguo precepto sagrado: Nosce te ipsum ${ }^{75}$.

La filiación espiritualista de la psicología krausista se atenuaría ostensiblemente a partir de la reedición de 1878 de las Lecciones de Giner, Soler y Calderón, que, «completamente refundida conforme a los últimos progresos de la antropología y la fisiología psicológica», suele considerarse como el primer testimonio de la llegada a España de las nuevas corrientes positivistas de la psicología europea ${ }^{76}$. Este giro, que ha de verse en el marco del proceso de «disolución doctrinal del idealismo krausista» consumado en los primeros años de la Restauración ${ }^{77}$, encontraría su máximo exponente en la figura de Urbano González Serrano, que asumió en 1873 la Cátedra de Psicología, Lógica y Ética del Instituto de San Isidro de Madrid. González Serrano, discípulo de Nicolás Salmerón y autor de varios estudios en los que dio a conocer los métodos y resultados de la psicología experimental francesa y alemana ${ }^{78}$, redactó también un importante manual escolar en el que, a pesar de mantener algunos lugares comunes del discurso tradicional, ya no se impugnaban de raíz las posiciones materialistas y se ofrecía a los alumnos una documentada revisión de los trabajos de autores como Wundt, Fechner, Ribot o Spencer ${ }^{79}$.

75 GINER De Los Ríos, F. (1874), Lecciones sumarias de psicología, Madrid, Imprenta de J. Noguera, pp. 3-4.

76 Cf. Giner De Los Ríos, F., SOler, E. y CAlderón, A. (1877), Lecciones sumarias de psicología, Madrid, Imprenta de Aurelio J. Alaria. La cita procede del subtítulo de esta edición, prologada en junio de 1878 y cuya relevancia histórica ha sido analizada por LAFUENTE, E. (1987), Los orígenes de la psicología científica en España: Las «Lecciones sumarias» de psicología de Giner de los Ríos, Investigaciones Psicológicas, 4, pp. 165-187.

77 Sobre este proceso, véase ABELLÁN (1984), pp. 512-534; o NúÑEZ RUIZ, D. (1975), La mentalidad positiva en España: desarrollo y crisis, Madrid, Túcar, pp. 77-109.

78 Entre ellos destacan las monografías La psicologia contemporánea: Exámen crítico de las opiniones y tendencias mas extendidas y autorizadas entre los modernos psicólogos sobre la ciencia del alma (Madrid, Imprenta de Gregorio Hernando, 1880) y La psicologia fisiológica (Madrid, Ricardo Fe, 1886). Sobre la evolución de González Serrano desde la metafísica idealista y la crítica del positivismo a la psicología experimental, véase JIMÉNEZ GARCÍA, A. (1996), El krausopositivismo de Urbano González Serrano, Badajoz, Diputación Provincial de Badajoz.

79 «De toda esta abundantísima literatura psicológica -concluía González Serrano- pueden recogerse datos bastantes para refutar todo sentido estrecho al concebir la naturaleza humana» (GONZÁlez SERRANO, U. (1880), Manual de psicología, lógica y ética (y rudimentos de derecho), Madrid, Imprenta de Gregorio Hernando, p. 5). 
En cualquier caso, otros docentes de formación krausista, como Romualdo Álvarez Espino en Cádiz, Juan Sieiro González en Orense, Agustín Arredondo García en Canarias o Eusebio Ruiz Chamorro en Madrid (Noviciado) siguieron impartiendo todavía en esos años unos contenidos claramente espiritualistas ${ }^{80}$, con lo que cabe suponer que la irrupción de la nueva psicología experimental tuvo, al menos inicialmente, un impacto mas bien limitado en el ámbito especifico de la educación secundaria.

Así pues, con todas las diferencias doctrinales que es posible establecer entre el eclecticismo, la neoescolástica o el krausismo, puede decirse que los docentes formados o alineados en sus filas participaron durante décadas de un mismo programa pedagógico que, articulado por el nuevo estado liberal, les llevó a transmitir a los estudiantes de secundaria una serie muy similar de axiomas sobre el psiquismo y la naturaleza humana. Desde un punto de vista educativo y cultural es, por tanto, esta confluencia espiritualista el hecho que interesa destacar aquí, y no las innumerables, innegables y consabidas divergencias entre estas corrientes filosóficas que, en un siglo que se había iniciado con la recepción del sensualismo y la ideología más radical y se cerraría bajo la égida de la ciencia positivista, se alternaron como reservorios ideológicos del poder político ${ }^{81}$.

\section{LA CULTURA DEL Yo}

En una sesión celebrada el 21 de enero de 1856 en el Ateneo de Madrid, el gran Pedro Mata se refería despectivamente al discurso psicológico dominan-

80 Como prueban los contenidos de los siguientes manuales: ÁlvarEz EsPINO, R. (1867), Nociones de lógica: Preparación al estudio de la psicología, Cádiz, Eduardo Gautier; SIEIRO GONZÁlEZ, J. (1872), Lecciones de filosofía, psicología y lógica, Orense, Imprenta de Gregorio Rionegro Lozano; ARREdondo GARCíA, A. (1875), Compendio doctrinal de psicología, lógica y filosofía moral, Santa Cruz de Tenerife, Benítez y C.a; y RuIz CHAMORRO, E. (1876), Psicología ó ciencia del alma, Madrid, Imprenta de Segundo Martínez.

81 En este sentido, resulta muy significativo que representantes de las tres corrientes combatieran la irrupción del positivismo durante los primeros años de la Restauración con argumentos muy similares, como prueban los célebres debates mantenidos en el Ateneo de Madrid durante el curso 1875-76. Sobre éstos, véase NúÑEZ RUIZ (1975), pp. 21-76; así como Mateos, A.I., Travieso, D., SÁnchez, R. y Blanco, F. (1997), El Ateneo de Madrid: una caja de resonancia para el debate sobre las relaciones entre ideología y discurso psicológico. En Blanco, F. (ed.) (1997), Historia de la psicología española: Desde una perspectiva socioinstitucional, Madrid, Biblioteca Nueva, pp. 69-108. 
te con el término de «yoísmo», calificándolo como una doctrina particularmente «falsa y estéril», incapaz de dar «una idea cabal de la razón humana» y generadora de un «divorcio absurdo de la fisiología y la psicología». Los «yoístas» -afirmaba Mata- «han hecho una entidad, el Yo, la conciencia, y sobre esta abstracción, sobre esta creación ontológica, quimérica, han fundado una [...] verdadera torre de Babel, donde todos hablan y ninguno se entiende» ${ }^{82}$. Reafirmándose en sus posiciones materialistas, Mata se enfrentaba, más que a un autor o escuela concreta, a todo un entramado cultural del que el espiritualismo psicológico constituía, como hemos visto, un resorte esencial. Pero, acorde con la autocomprensión, la inspiración ideológica y los intereses sociopolíticos de las élites liberales del segundo tercio del siglo XIX, su implantación educativa ha de entenderse, además, como un intento muy significativo de articular una pedagogía de la subjetividad, esto es, de aleccionar a los alumnos en una determinada visión de sí mismos y forjar en ellos un determinado patrón de reflexividad. Desde este punto de vista, la doctrina espiritualista difundida en las aulas durante buena parte del siglo XIX aparece no sólo como un corpus deudor de ciertos valores e intereses, sino también como una singular «tecnología del yo» destinada a proyectarse en la sociedad española de la época y conformar una cultura psicológica muy correcta ${ }^{83}$.

La pertinencia de esta perspectiva de análisis resulta manifiesta si se examinan, por ejemplo, los materiales escolares redactados por los propios alumnos en sus clases de «psicología» o se constata la extraordinaria proyección cultural del «yoísmo» en la España de la segunda mitad del siglo XIX. Así, los apuntes tomados por el alumno José Soriano y Castro en el curso 1848-49 a partir de las lecciones de Monlau en el Instituto de San Isidro ${ }^{84}$, consignan afirmaciones tales sobre la dualidad de cuerpo y alma, sobre la naturaleza de

82 Mata, P. (1858), Filosofía española: Tratado de la razón humana con aplicación a la práctica del Foro, Madrid, Carlos Bailly-Baillière, pp. 47-48. Sobre las ideas psicológicas de Mata puede consultarse la monografía de LÓPEZ FERNÁNDEZ, M. ${ }^{a}$ N. (1993), La psicología en la obra de Pedro Mata y Fontanet, Valladolid, Universidad de Valladolid.

83 Tal como ha sugerido Jan Goldstein en el marco de su espléndido análisis de la difusión del espiritualismo cousiniano en la Francia del siglo XIX. Cf. GoldsteIN, J. (1994), Foucault and the post-revolutionary self: The uses of Cousinian pedagogy in nineteenthcentury France. En Foucault and the Writing of History, Oxford, Blackwell, pp. 99-115; y GOLDSTEIN (2005), pp. 13-15. Sobre el concepto y la visión foucaultiana de las «tecnologías del yo», Foucault, M. (1990), Tecnologías del yo. En Tecnologías del yo y otros textos afines, Barcelona, Paidós/ICE-UAB, pp. 45-94.

84 Los apuntes del joven Soriano forman un cuaderno manuscrito de 43 hojas titulado Compendio de psicología que se conserva en la Biblioteca Nacional (Madrid). 
ésta como «fuerza que anima al hombre» o sobre las cualidades del yo (que «es siempre uno, idéntico y activo» a la par que «sensible, inteligente y libre»), que difícilmente pasaron desapercibidas a las decenas de miles de estudiantes de secundaria que hubieron de escucharlas durante décadas. El mismo Santiago Ramón y Cajal, por ejemplo, refiere en sus memorias haber dedicado un gran esfuerzo a la lectura de la «psicología de Monlau» durante sus estudios de bachillerato en Huesca en la década de 1860. Y cabe inferir que sus contenidos y su orientación doctrinal tuvieron una notable influencia sobre él, pues, todavía en sus años de estudiante de medicina en Zaragoza, Cajal reconocía haber sido un «ferviente y exagerado espiritualista» y llegaba a confesar que, por aquella época, sus veleidades filosóficas pasaban sistemáticamente por «refutar, ante mis camaradas un poco desconcertados, la existencian del mundo exterior, el noumenon misterioso de Kant, afirmando resueltamente que el yo, o por mejor decir, mi propio yo, era la única realidad absoluta y positiva» ${ }^{85}$.

Con todo, el atractivo y la difusión del espiritualismo psicológico en la España del segundo tercio del siglo XIX deben verse, más allá de sus evidentes afinidades burguesas, en el marco de su mayor compatibilidad con los dogmas tradicionales en torno a la unidad, espiritualidad e inmortalidad del alma o la existencia de la libertad moral. No por casualidad, el auge y la promoción educativa de la psicología ecléctica, neoescolástica y krausista que hemos revisado en este artículo se dio en un periodo en el que otras teorías y disciplinas que, como el darwinismo, la paleontología o la embriología evolucionista, implicaban un fuerte cuestionamiento de la imagen del ser humano sostenida por la ortodoxia religiosa, fueron objeto de intensas y enconadas controversias e inspiraron incluso diversos intentos de «conciliación» por parte de los científicos españoles ${ }^{86}$. Análogamente, el yo sustancial, unitario y activo de la psicología espiritualista decimonónica ha de entenderse, en última instancia, como un axioma orientado a contrarrestar las fuertes tendencias de reducción, naturalización y fragmentación del psiquismo implícitas en la aproximación objetivante, analítica y experimental propia de la ciencia moderna ${ }^{87}$. Por ese motivo, el sensualismo y la frenología primero, y la psicolo-

85 RAMÓn y CAJAL, S. (2006), Recuerdos de mi vida, Barcelona, Crítica (original de 1923), p. 274.

86 Cf. Pelayo, F. (1999), Ciencia y creencia en España durante el siglo XIX: La paleontología en el debate sobre el darwinismo, Madrid, CSIC, pp. 47-80, 113-134 y 307-340.

87 Una interpretación similar puede leerse en BlanCO, F. y CASTRO, J. (2005), La significación cultural de la psicología en la España restaurada. En JIMÉNEZ, A., ORDEN, R. y AGEN- 